\title{
Economic hardship and extreme voting under the economic crisis
}

A comparison between Italy and Greece

Camille Bedock and Pavlos Vasilopoulos

\section{(2) OpenEdition Journals}

Electronic version

URL: http://journals.openedition.org/ress/2998

DOI: $10.4000 /$ ress.2998

ISSN: 1663-4446

Publisher

Librairie Droz

Printed version

Date of publication: 15 May 2015

Number of pages: 177-196

ISSN: 0048-8046

\section{Electronic reference}

Camille Bedock and Pavlos Vasilopoulos, "Economic hardship and extreme voting under the economic crisis », Revue européenne des sciences sociales [Online], 53-1 | 2015, Online since 01 January 2018, connection on 06 May 2019. URL : http://journals.openedition.org/ress/2998 ; DOI : $10.4000 /$ ress.2998 


\title{
ECONOMIC HARDSHIP AND EXTREME VOTING UNDER THE ECONOMIC CRISIS
}

\section{A COMPARISON BETWEEN ITALY AND GREECE}

\author{
CAMILLE BEDOCK \& PAVLOS VASILOPOULOS \\ Sciences Po Bordeaux, Centre Émile Durkheim / Sciences Po Paris, CEVIPOF \\ camille.bedock@scpobx.fr / pavlos.vasilopoulos@sciencespo.fr
}

\begin{abstract}
One of the most important implications of the economic crisis in Europe is the withering away of mainstream parties. This is particularly evident in Southern Europe, where the current crisis challenges the stability of party systems that have lasted for decades. This article aims at exploring an aspect of economic voting that has not been investigated in depth: the impact of the perceived degradation of an individual's standard of living on the propensity to cast a vote for radical parties, using the case of the 2014 European election in Greece and Italy. The results show that this impact greatly varies across political systems. In the case of Italy, the degradation of the standard of living has not led Italian voters to be more prone to endorse far-left or far-right alternatives, as SEL and the Northern League have not switched their traditional ideological focus after the economic crisis unraveled. On the contrary, in Greece, both SYRIZA and Golden Dawn have managed to attract the voters who lost the most during the crisis, either through anti-austerity rhetoric or by blaming immigrants for the economic downturn.
\end{abstract}

Keywords: economic hardship, European elections, Greece, Italy, radical parties, vote.

Résumé. Une des implications principales de la crise économique en Europe est l'érosion des partis dominants. Ceci est particulièrement évident en Europe du Sud, où la crise vient ébranler des systèmes partisans qui avaient parfois été stables pendant des décennies. Cet article vise à explorer un aspect de la théorie économique du vote qui n'a pas fait l'objet d'enquêtes approfondies: l'impact de la perception d'une dégradation des conditions de vie sur la propension à voter pour un parti radical, en s'appuyant sur le cas des élections européennes de 2014 en Grèce et en Italie. Les résultats montrent que cet impact est fortement variable d'un système à l'autre. Dans le cas italien, la dégradation des conditions de vie n'a pas conduit les électeurs italiens à être plus prompts à soutenir des alternatives radicales à gauche ou à droite, puisque SEL et la Ligue du Nord n'ont pas modifié leurs orientations idéologiques traditionnelles après l'éclatement de la crise. Au contraire, en Grèce, SYRIZA et Aube dorée ont été à même d'attirer à eux beaucoup des électeurs ayant perdu le plus pendant la crise, soit par une rhétorique anti-austérité, soit en blâmant les immigrants pour l'ampleur de la crise économique.

Mots-clés: adversité économique, élections européennes, Grèce, Italie, partis radicaux, vote. 


\section{INTRODUCTION}

The theory of economic voting offers useful insights into the way that the economic crisis has affected the electoral behavior of European publics. Economic voting theory states that when the economy goes well voters will tend to reward the government, while on the contrary when the economy goes bad voters will tend to punish the government by supporting the opposition (Lewis-Beck and Stegmaier, 2007). The premises of the economic voting theory have received strong support, time and again, across different national contexts and election types (Anderson, 2000; Nezi, 2012; Fraile and Lewis-Beck, 2010; Fraile and Lewis-Beck, 2012). Yet the European economic crisis has created the demise of not only incumbent parties but in a number of countries has also caused a landslide for the whole political system, characterized by the shrink of mainstream parties and the rise of new populist parties placed on the both ends of the ideological spectrum. This was particularly felt in the crisis ridden European South. In both Greece and Italy, the economy had profound consequences for the political system that exceed the simple reward-punishment hypothesis between the incumbent and the challenger and apparently turned into a punishment for all mainstream parties. This has been illustrated in particular by a drastic redesigning of the political offer in both countries over the past five years, with the collapse of both mainstream parties in Greece (Panhellenic Socialist Movement [PASOK] and New Democracy [ND]) and the electoral success of the Coalition of the radical left (SYRISA) and Golden Dawn in Greece, and the sudden boom of the Five Star Movement ( $\left.\mathrm{M}_{5} \mathrm{~S}\right)$ in Italy in the 2013 general election. This is the point where traditional economic voting theory reaches its limits, as it does not differentiate between the type of parties that voters prefer in different contexts during economic hard times (Kriesi, 20I4).

The aim of this article is twofold. First, by drawing on data from the seminal 20I4 European Elections, it looks at the impact of the economy on the vote for far left and right parties in two South-European countries, Italy and Greece. Second, taking into account the differential exposure to the crisis between the two countries, the article aims to advance some explanations about the conditional impact of economic hardship on voting choice. Both 
Italy and Greece have suffered severely from the European economic crisis and both have seen the withering away of mainstream center left and right parties and the strengthening of populist parties from both ends of the political spectrum. That said, they also present interesting differences: whereas in Greece, the collapse of the mainstream parties has led to the strengthening of extreme parties in both sides of the political spectrum, Italy has not seen the development of far right and far left alternatives. Rather, populist alternatives with strong anti-politics overtones $\left(\mathrm{M}_{5} \mathrm{~S}\right)$ have flourished, while the main center-left party in Italy has shown a relative resilience, and has even witnessed a great electoral success in the 2014 European election. Therefore, the far-left and far-right alternatives appear stronger in Greece than in Italy, and the 20I4 European election in Italy contrasts sharply with the expectation of the economic voting theory. As a consequence, the two countries offer a fertile ground to test the existence of a link between hardship and extreme voting.

\section{I.ECONOMIC PERCEPTIONS}

\section{AND VOTING BEHAVIOR AFTER THE ECONOMIC CRISIS}

Bartkowska and Tiemann show that economic voting is a more complex phenomenon in the European elections than it is in the national elections. Indeed, "the specific economic policy domains of European Union (EU) institutions vis-à-vis the national governments are often only vaguely defined so that voters have a hard time identifying responsible politicians or speculating on the potential differences an allegedly more competent alternative might make" (Bartkowska and Tiemann 20I4, p.I). Comparing the 2004 and 2009 elections, they show that voters are more inclined to cast an economic vote when they consider that the management of the economy is a domain of their respective member state. Lobo and Lewis-Beck (2012) reach similar results comparing specifically economic voting in Southern European countries (Spain, Italy, Greece and Portugal) and showing that a heightened perception of the economic responsibility of the EU reduces the magnitude of economic voting. 
More generally, these authors have reflected on the link between the attribution of responsibility to Europe and national governments and economic voting. Furthermore, one of the important premises of the economic voting theory is that it is not the personal financial situation of voters that is decisive for the economic vote, but the perception of the national economy (Duch and Stevenson, 2008; Lewis-Beck and Stegmaier, 2000). In the case of Greece, analyzing the elections of 2004 and 2009, Nezi (2012) demonstrated that retrospective sociotropic evaluations about the economy are associated with support for the governing coalition or party even when ideology and party identification are controlled for. Kriesi (2012) has shown conclusively that the impact of economic voting is greater in situation of economic recession, and that incumbent parties have been particularly severely punished in the recent elections. Lewis-Beck and Nadeau (2012) showed that economic voting in Southern Europe (Portugal, Italy, Ireland, Greece and Spain) is much more pronounced that in the rest of the continent. They consider that this result suggests that the electorates in these countries hold the governments tightly accountable of the economic crisis they face.

This article goes past traditional perspectives on economic voting. Indeed, what we aim to understand is the impact of the evolution of one's personal economic situation on the propensity to cast a vote for an extreme party. In other words, the article deals with egocentric evaluations rather than sociotropic evaluations. There are two reasons for this. First, given the extent of the economic crisis and the vast deterioration of the standard of living among Greeks and Italians, the number of respondents who consider that the economy has got better is extremely low. Second, in this context of very bad economic times, citizens who consider that the economy has got better are more likely to have engaged in a posteriori motivated reasoning processes, i.e. evaluating the state of the economy based on their vote choice, rather than vice versa.

What is however the mechanism that links economic hardship and propensity to vote for non-mainstream parties? As Kriesi (2014, p.519) points out, disaffected voters have several options at hand: turning to established opposition parties, nurturing resentment against all mainstream parties, or turning against 
political parties altogether by abstaining or supporting "anti-parties". Therefore, one could expect that the economic crisis leads voters not only to punish incumbents, but also to be more prone to support radical political alternatives. We consider here vote for far-right and far-left parties as a "proxy" expressing resentment against all mainstream parties. We exclude the vote for populist parties such as the $\mathrm{M}_{5} \mathrm{~S}$ in Italy, due to its lack of institutionalization and ambiguous ideological profile (Bordignon and Ceccarini, 20I3). Moreover, we do not analyze actual votes but rather propensity to vote scores, i.e. asking respondents how likely it is that they will ever vote for the party in question. Propensity to vote (PTV) scores are valid measures of present electoral utilities of each political party (Van der Eijk et al., 2006). Contrary to multinomial logit models with a nominal dependent variable consisting of parties with a large number of voters, PTV scores offer the advantage of observing the electoral utility of each party without having to exclude minor parties from the analysis. This is particularly useful for our current analysis as there is increased party fragmentation in both countries. In particular, seven parties in both Italy and Greece gathered a vote share of over three percent in the 20I4 European election.

\section{THE 2014 EUROPEAN ELECTION IN ITALY}

The 20I4 European elections represent a tremendous success for Matteo Renzi, who has secured a very large and widely unexpected electoral victory, with $40.8 \%$ of the votes, the largest share ever won by a centre-left party in Italy. As a consequence, the Democratic Party (PD) now constitutes the largest group of MEPs in the European Parliament. According to D’Alimonte (2014, p.99), this success can be attributed to two factors: the ability of bringing to the polls the voters who had chosen the PD in 2013, and the enlargement of the consensus, with the PD gaining 2.5 million voters while the electoral turnout declined sharply compared to the 2013 general election. The only other party who has gained votes in absolute terms is the far right Northern League (LN), which managed to secure 300 ooo votes in addition to the ones received in 2013 , increasing by 2.3 percentage points the result of 2013 . The $\mathrm{M}_{5} \mathrm{~S}$, despite a decline compared to the 2013 elections, still achieved to obtain 2 I.2\% of 
the votes, while Forza Italia achieved $17 \%$ of the votes. The LN has obtained $6.2 \%$ of the votes nationally, while the list "Other Europe with Tsipras" led by Left, Ecology, Freedom (SEL) and allied with the Communist Refoundation and other small parties, obtained $4 \%$ of the votes. Finally, the junior partner in government of the Democratic Party, the New-Center Right (NCD), a splinter from the former People of Freedom (PDL), allied with the centrists of the Union of the Center (UDC), managed by a small margin to gain representation in the European Parliament by overcoming the $4 \%$ threshold.

In one word, the 20I4 European election is a clear test for the traditional assumptions of the economic voting theory, according to which the governing parties are disadvantaged in times of economic crisis, particularly so during second-order elections (Reif and Schmitt, 1980; Van der Eijk and Franklin, 1996). Hix and Marsh (2007), working specifically on the European elections also confirmed the explanatory power of the second-order model, showing that voters primarily use the European elections to punish incumbents. Nevertheless, the effects of the economic crisis in Italy on voting appear ambivalent, which may be explained by the inherent volatility of the Italian party system since 1993, which been labeled as a process of deinstitutionalization by Chiaramonte and Emanuele (20I4). These surprising results are due in great part to the change of leadership of the PD. In November 20I3, Renzi managed to be elected leader with more than $68 \%$ of the votes in the primaries, gathering I.6 million voters, before forming his own government a couple of months later with the support of the New-Center Right of Alfano. It can be argued that the "honeymoon effect" from which the Renzi government has benefited has clearly counteracted the incumbent punishment effect. Moreover, the relationship between economic crisis and the propensity to vote for far-left or far-right party has not been investigated so far. 
Table I. Electoral Results in the 2009 and 20I4 European Elections (Italy)

\begin{tabular}{|l|c|c|c|}
\hline & 2009 & 2014 & $2014-2009$ \\
\hline DEMOCRATIC PARTY (PD) & 26.12 & 40.81 & +14.69 \\
\hline FIVE STAR MOVEMENT (M5S) & N/A & 21.15 & +21.15 \\
\hline THE PEOPLE OF FREEDOM (PDL)* & 35.26 & 16.81 & -18.45 \\
\hline $\begin{array}{l}\text { NEW CENTER-RIGHT (NDC)-UNION OF } \\
\text { THE CENTRE (UDC)** }\end{array}$ & 6.51 & 4.38 & -2.13 \\
\hline THE OTHER EUROPE (SEL+ RC)*** & 6.52 & 4.03 & -2.49 \\
\hline ITALY OF VALUES (IDV) & 8.00 & N/A & -8.00 \\
\hline NORTHERN LEAGUE (LN) & 10.21 & 6.15 & -4.06 \\
\hline
\end{tabular}

Note: entries are percentage. Only parties obtaining more than $4 \%$ of the votes are reported.

*: After the splinter of the People of Freedom, the score of 2014 refers to the score obtained by Forza Italia alone.

**: In 2009, the Union of the Centre ran on its own. The NDC is a splinter of the People of Freedom. *****: This electoral alliance ran under two lists un 2009: Rifondazione Comunista and Comunisti Italiani and Sinistra e libertà).

\section{THE 2014 EUROPEAN ELECTION IN GREECE}

Table 2. Electoral Results in the 2009 and 2014 European Elections (Greece)

\begin{tabular}{|l|c|c|c|}
\hline & 2009 & 2014 & $2014-2009$ \\
\hline PASOK & 36.64 & $8.02 *$ & -28.62 \\
\hline NEW DEMOCRACY (ND) & 32.29 & 22.72 & -9.57 \\
\hline COMMUNIST PARTY (KKE) & 8.35 & 6.11 & -2.24 \\
\hline SYRIZA & 4.7 & 26.57 & 21.87 \\
\hline GOLDEN DAWN (GD) & 0.46 & 9.39 & 8.93 \\
\hline THE RIVER & N/A & 6.6 & 6.6 \\
\hline
\end{tabular}

Note: entries are percentages. *: PASOK ran under the name of Olive. 
The 20I4 European elections in Greece signified a historical victory for the far-left, as they won their first ever election in Greek political history. On the one hand, SYRIZA managed to gain an unprecedented $26.6 \%$ of the votes, a result that is almost equivalent to the one obtained in the second Greek national election in June 2012 (26.9\%). On the other hand, the members of the coalition government reached once more historically low electoral shares. New Democracy, the major party in the government coalition, obtained $22.7 \%$ of the vote, a fall of nearly $7 \%$ compared to the June 2012 election and $10 \%$ compared to the 2009 European election. As for PASOK, the once ruling party of Greece, the 20I4 European election signified an unprecedented $26 \%$ loss in the vote share compared to 2009 as the party managed to gain only $8 \%$ of the national vote. An additional important and worrying development is the continuous rise of the neo-nazi Golden Dawn, which managed to secure $9.4 \%$ of the vote $(6.9 \%$ in 2012$)$, despite the fact that the party is being prosecuted for forming a criminal gang and that 9 out of I 8 of its MPs are imprisoned ahead of the trial. Finally, it is worth noting that to Potami (the River), a new centrist party led by a prominent television journalist that ran for the first time gained $6.6 \%$ of the vote while the Greek Communist Party's (KKE) electoral share was 6.1\%.

Overall, and unlike Italy, the electoral results in Greece followed the general pattern registered in the rest of Europe: the punishment of the ruling parties, albeit in a different fashion: whereas in Italy the main government party obtained an unexpectedly large electoral victory, the magnitude of the withering away of mainstream parties in the case of Greece is cataclysmic. On the one hand, the parties of the ruling coalition (PASOK and ND) lost in absolute terms I.2 million votes, reaching new historical lows that were unimaginable a few years back. On the other hand, SYRIZA achieved an important victory that consolidated the upward electoral tendency that had started on the onset of the Greek debt crisis in 2010, bringing the party from a feeble $4.60 \%$ in the 2009 general election to the gates of governance. Which are however the determinants of the Greek far-left and far-right votes? Further, how is economic hardship associated with the propensity of casting 
a vote for radical parties? Up until now no work has investigated the relationship between economic hardship and the propensity to vote for the farleft and far-right parties in Greece.

\section{METHODOLOGY AND DATA}

The following analysis is based on the survey "Comparative Electoral Dynamics in the European Union in 2014", coordinated by Nicolas Sauger, Renaud Dehousse and Florent Gougou (2015) and fielded in Austria, France, Germany, Italy, Spain, Portugal and Greece. The polls in each country have been conducted by the TNS Sofres. The sample size is Ior7 for Greece and 4003 for Italy. Our dependent variable is the propensity to vote score (PTV) for the Italian and Greek far left (SEL and SYRIZA) and far right (Northern League and Golden Dawn) parties. The variable is an interval ranging from o to Io tapping the likelihood of ever voting for a particular party. In our investigation of the propensity to vote for the far left and far right in Italy and Greece, we construct two OLS models. Model I includes standard demographics (age, gender, education) as well as measures of economic hardship. For matters of comparability for the two countries, we have created dummy separating respondents holding a university degree and the others, in order to control for the effect of high education. In addition, we control for income, whether the respondent is currently unemployed, precarious or works without a contract. On top of these we add an index of economic hardship calculated as the difference between a respondent's current standard of living compared to what it was five years ago (both measured in ro point scales): Hence, the index ranges from - Io to Io, where positive values indicate an increase in economic hardship since the beginning of the crisis in 2009. The distribution of hardship for Greece and Italy is presented in Figures I and 2. 
Figure I. Level of economic hardship in Greece

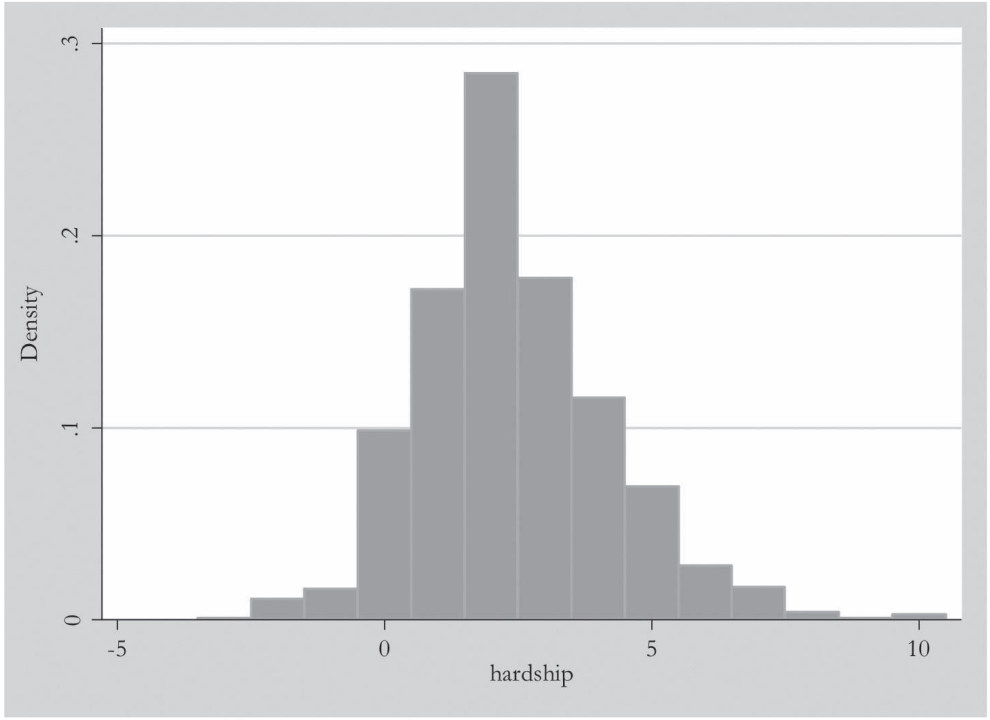

Figure 2. Level of economic hardship in in Italy

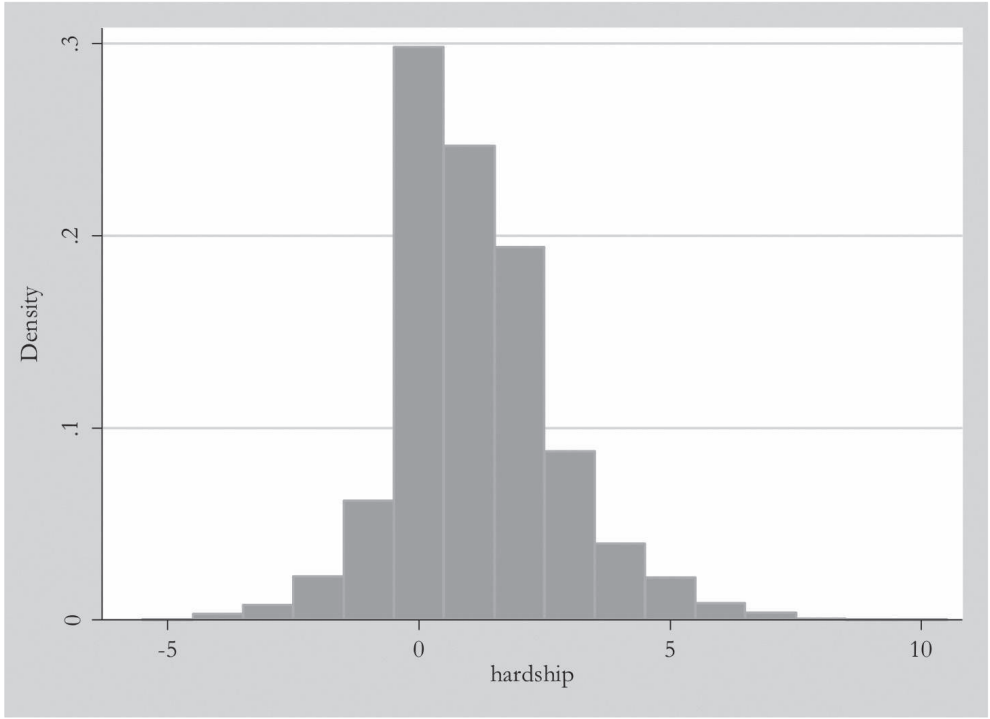


The two graphs suggest that the Greek respondents have the feeling to have been more severely struck by the economic crisis than their Italian counterparts. Indeed, in Italy, around 30\% of the respondents evaluate their current economic situation in the same way as in 2009, whereas $10 \%$ consider this situation has been improved, and 60\% that is has deteriorated to some degree. In Greece, only 3\% of the respondents consider that their standard of living has improved in the last five years, while only ı\% think that this standard is equivalent to what it was five years ago. Therefore, an overwhelming proportion of the Greek respondents (87\%) consider that their economic situation has deteriorated in the last five years. In other words, the matter of economic hardship appears as a particularly crucial development, notably in Greece.

Model 2 uses the same variables as Model I with additional controls for two key political values associated with the economy, both measured in Io-point scale. The first measures perceived economic threat by immigration ("immigration is a threat to our jobs"). This item is key for investigating the rise of far right parties. Past research has illustrated that in economic hard times, negative attitudes toward immigrants tend to increase as natives in times of economic crises are more likely to perceive immigrants as competitors for scarce resources (Citrin et al., 1997). This finding has been highlighted for the current European crisis (Dancygier and Donnelly, 20I4). The issue of immigration, especially in regard with the prospects for employment for the Greeks, has been key for the Golden Dawn, expressed with slogans such as "Jobs for Greek workers" or "Every foreign worker creates one unemployed Greek”. In addition, the neo-nazi party was particularly active in working class areas with high unemployment rates, by forming trade unions and even physically assaulting immigrant workers. The second item taps attitudes toward income redistribution ("wealth should be much more redistributed"), a claim which is central in the manifestos of both SYRIZA and SEL. For instance, the programme of "Other Europe with Tsipras" puts a strong emphasis on the creation of a European Plan for Employment to redistribute wealth and jobs to 
unemployed people across Europe ${ }^{1}$. The need to increase taxation on higher incomes in order to address the growing income inequality after the onset of the Greek crisis is the spearhead of SYRIZA's economic program.

\section{RESULTS}

Tables 3 and 4 report the determinants on the propensity to vote for the far left and the far right in both countries respectively in the 20I4 European election.

Table 3. The Determinants of the propensity to vote for the far left in Greece and Italy

\begin{tabular}{|c|c|c|c|c|c|c|c|c|}
\hline \multirow[b]{2}{*}{ AGE } & \multicolumn{4}{|c|}{ ITALY } & \multicolumn{4}{|c|}{ GREECE } \\
\hline & $-0.02 * * *$ & $(0.00)$ & $-0.03 * * * *$ & $(0.00)$ & 0.01 & $(0.01)$ & 0.01 & $(0.01)$ \\
\hline FEMALE & 0.31 ******* & $(0.10)$ & $0.28 * * * *$ & $(0.10)$ & 0.24 & $(0.27)$ & 0.31 & $(0.26)$ \\
\hline HIGH EDUCATION & $0.44 * * * *$ & $(0.11)$ & $0.34 * * * *$ & $(0.11)$ & -0.14 & $(0.29)$ & -0.33 & $(0.28)$ \\
\hline INCOME & $-0.04 * *$ & $(0.02)$ & $-0.04 *$ & $(0.02)$ & -0.06 & $(0.08)$ & 0.00 & $(0.08)$ \\
\hline UNEMPLOYED & -0.15 & $(0.17)$ & -0.11 & $(0.17)$ & 0.01 & $(0.33)$ & 0.04 & $(0.32)$ \\
\hline PRECARIOUS & $-0.32 * *$ & $(0.16)$ & $-0.31 * *$ & $(0.15)$ & 0.36 & $(0.37)$ & 0.37 & $(0.36)$ \\
\hline NO CONTRACT & -0.61 米** & $(0.17)$ & $-0.59 * * * *$ & $(0.16)$ & -0.32 & $(0.33)$ & -0.28 & $(0.32)$ \\
\hline HARDSHIP & $-0.15 * * * *$ & $(0.03)$ & $-0.12 * * *$ & $(0.03)$ & $0.19 * *$ & $(0.08)$ & $0.17 * *$ & $(0.08)$ \\
\hline $\begin{array}{l}\text { WEALTH SHOULD } \\
\text { BE MORE } \\
\text { REDISTRIBUTED }\end{array}$ & & & $0.16 * * *$ & $(0.02)$ & & & $0.41 * * * *$ & $(0.06)$ \\
\hline $\begin{array}{l}\text { IMMIGRANTS } \\
\text { ARE A THREAT } \\
\text { TO OUR JOBS }\end{array}$ & & & $-0.26 * * * *$ & $(0.02)$ & & & $-0.14 * * * *$ & $(0.04)$ \\
\hline CONSTANT & 4.00***** & $(0.21)$ & $4.41 * * * *$ & $(0.29)$ & $3.73 * * * *$ & $(0.62)$ & 1.53* & $(0.79)$ \\
\hline OBSERVATIONS & 3.722 & & 3.696 & & 867 & & 859 & \\
\hline$R^{2}$ & 0.03 & & 0.11 & & 0.02 & & 0.09 & \\
\hline
\end{tabular}

Note: entries are OLS regression coefficients with their standard errors in parentheses.

**** $p<0.01$, *** $p<0.05, * p<0.1$ 
Table 4. The Determinants of the propensity to vote for the far right in Italy and Greece

\begin{tabular}{|c|c|c|c|c|c|c|c|c|}
\hline \multirow[b]{2}{*}{ AGE } & \multicolumn{4}{|c|}{ ITALY } & \multicolumn{4}{|c|}{ GREECE } \\
\hline & $-0.01 * * *$ & $(0.00)$ & -0.00 & $(0.00)$ & -0.03 ***** & $(0.01)$ & $-0.03 * * * *$ & $(0.01)$ \\
\hline FEMALE & $-0.22 * *$ & $(0.11)$ & -0.16 & $(0.10)$ & -0.72 *⿻丷木米米 & $(0.20)$ & $-0.58 * * *$ & $(0.19)$ \\
\hline HIGH EDUCATION & -0.12 & $(0.12)$ & -0.06 & $(0.11)$ & $-0.43 * * *$ & $(0.22)$ & -0.03 & $(0.21)$ \\
\hline INCOME & 0.03 & $(0.02)$ & 0.03 & $(0.02)$ & $0.12 *$ & $(0.06)$ & $0.10 *$ & $(0.06)$ \\
\hline UNEMPLOYED & $0.31 *$ & $(0.18)$ & 0.31 * & $(0.16)$ & -0.04 & $(0.25)$ & -0.07 & $(0.24)$ \\
\hline $\mathrm{CDD}$ & $-0.30 *$ & $(0.16)$ & $-0.3 \mid$ I**⿻丷木 & $(0.15)$ & 0.32 & $(0.28)$ & 0.25 & $(0.26)$ \\
\hline NO CONTRACT & -0.22 & $(0.17)$ & -0.23 & $(0.16)$ & -0.00 & $(0.25)$ & -0.12 & $(0.24)$ \\
\hline HARDSHIP & -0.00 & $(0.03)$ & -0.02 & $(0.03)$ & 0.21 ****** & $(0.06)$ & 0.16 **** & $(0.06)$ \\
\hline $\begin{array}{l}\text { WEALTH SHOULD } \\
\text { BE MORE } \\
\text { REDISTRIBUTED }\end{array}$ & & & -0.32 ***** & $(0.02)$ & & & -0.06 & $(0.04)$ \\
\hline $\begin{array}{l}\text { IMMIGRANTS } \\
\text { ARE A THREAT } \\
\text { TO OUR JOBS }\end{array}$ & & & 0.30***** & $(0.02)$ & & & 0.28 ***** & $(0.03)$ \\
\hline CONSTANT & 2.72 ***** & $(0.22)$ & 3.30***** & $(0.29)$ & $2.64 * * * *$ & $(0.47)$ & 1.49** & $(0.58)$ \\
\hline OBSERVATIONS & 3,719 & & 3,692 & & 866 & & 858 & \\
\hline$R^{2}$ & 0.00 & & 0.15 & & 0.04 & & 0.14 & \\
\hline
\end{tabular}

Note: entries are OLS regression coefficients with their standard errors in parentheses.

***** $p<0.01$, *** $p<0.05$, * $p<0.1$

Starting with the propensity to vote for the far-left, our results indicate some important divergences between the two parties. It appears that while in Italy far left voters have a coherent demographic profile, the same does not apply in the case of Greece. In particular, potential SEL voters appear to be younger compared to the rest of the electorate, a finding that is in alignment with research on the far left from other European countries and that highlights the tendency of younger voters to vote for libertarian and non mainstream parties (Bowyer and Vail, 20II; Vasilopoulos et al., 20I4). SEL prospective voters are predominantly female, which could perhaps be attributed to the higher dependence of women on welfare compared to men (Dolezal, 2010). Furthermore, Italian far left prospective voters come from high educational backgrounds. This is not surprising given that there is a strong link between education and endorsement 
of libertarian values (Knutsen, 2004). Overall, these demographic characteristics are typical of far left voters in other countries (Bowyer and Vail, 20II; Vasilopoulos et al., 20I4). Moving on to the rest of the independent variables, income yields a negative and significant coefficient on the propensity to vote for the Italian far left, while surprisingly the same is the case with the precarious and individuals who work without a contract. Finally, economic hardship has a significant effect on the propensity to vote for SEL, but in the reverse direction as expected: the lower the deterioration of income over the last five years, the higher the propensity to vote for the Italian far left party. This surprising result may be linked with the profile of far-left economic voters in Italy who are highly educated and prone to endorse post-materialist values. Moreover, the main party in the far-left coalition, SEL, has attempted to position itself as a true center-left government party (Bordandini, 20I3), before the change of strategy of the European elections of 2014 in order to get closer to other communist forces such as Communist Refoundation. As a consequence, this could explain why this party did not appeal primarily to the "losers" of the economic crisis.

As regards their Greek counterparts, our results suggest that voters who are positively inclined toward SYRIZA carry a mixed demographic profile, which is rather atypical of far left voters. In particular, age, gender, income, education and professional status all fall short of reaching statistical significance. What appears as the only significant predictor of the propensity to vote for the Greek far left is economic hardship, with a higher loss of income since the advent of the crisis being associated with a higher propensity to vote for SYRIZA. These results are not surprising. It appears that in its transition from a minor fringe party to the winner of the 2014 European election SYRIZA attracts a heterogeneous electorate, with the only common characteristic being significant income losses since the beginning of the crisis.

Moving on to the assessment of the attitudinal profile of the Greek and Italian far left voters (Model 2) results suggest that in both cases, being for a strong redistribution of income is a positive and significant predictor of the propensity to vote for the far left in both countries, although the relationship appears to be stronger for the Greek case. As for economic insecurity due to 
immigration, it is negatively associated with the propensity to vote for both far left parties, and in this case the association is stronger for the case of SEL. Overall, our findings suggest that SEL and SYRIZA do not appeal in the same way to voters who lost the most during the crisis. In the case of Italy, the perception of a higher loss of income during the crisis negatively affects the propensity to vote the far left, whereas in the case of Greece, economic hardship has a positive effect on the propensity to endorse SYRIZA. The main explanation one can advance to explain such discrepancy is the existence of strong sociodemographic differences between SEL and SYRIZA voters. Is there any common ground between far left and far right prospective voters in the two countries?

Table 2 reports the determinants of the propensity to vote for the far right Northern League and the Golden Dawn. Contrary to what we found for far left parties, overall findings suggest some demographic similarities in voters' characteristics for the two cases, as both parties appear to appeal to a young electorate predominantly consisting of male voters. Yet, at the same time our findings indicate some interesting divergences. On the one hand, it appears that in Greece the Golden Dawn appeals to voters with a low level of education, coming from higher income classes and who have experienced significant loss of income during the last five years. On the other hand, the prospective voters of the Northern League appear to come from all income and educational classes and are predominantly unemployed, while being in a precarious work state yields a negative coefficient on the propensity to vote for the far right. Moving on to the assessment of political attitudes, we find that a common theme of the far right in both countries is the beliefs that the immigrants take away the jobs of natives. But while Northern League voters appear to endorse economic conservative political values, the Golden Dawn voters have a mixed economic left-right profile. Economic hardship does not have a statistically significant effect on the propensity to vote for the Northern League. This may be due to the fact that the ideological profile of the party is not so much based on gathering the "losers" of the economic crisis, but rather on the appeal to voters holding authoritarian values and on voters of the North claiming for more territorial autonomy, while still defending liberal economic alternatives. 
Several authors have demonstrated the shift of the Northern League voters towards the extreme right, with a stronger focus on issues such as immigration and European integration. In other words, the Northern League has positioned itself in the recent years primarily as an anti-European, anti-immigrant party (Passarelli, 20I3). Finally, it is worth mentioning that the economic hardship variable has a strong positive effect on the propensity to vote for the Greek neonazi party, even after controlling for attitudinal characteristics. All else equal, the higher the loss of income since the beginning of the crisis, the higher the probability of voting for the Golden Dawn. This finding is not surprising: in accordance with its national socialist platform, the Golden Dawn promotes radical solutions regarding the economic crisis, which include canceling the Greek bail-out deal, writing off of the majority of the Greek debt and restructuring the national economy through the expulsion of foreign workers and the protection of Greek businesses. In this way, the radical neo-nazi platform of the Gold Dawn managed to appeal to xenophobic layers of the Greek society who saw their quality of life vastly deteriorating since the beginning of the crisis.

\section{CONCLUSION}

The example of the 20I4 European election shows, thanks to the comparison of Greece and Italy, that the impact of economic hardship on the propensity to vote for far-left and far-right parties differs across political systems. In the case of Italy, the degradation of the standard of living does not lead Italian voters to be more prone to endorse far-left or far-right alternatives. In the case of the far-left, this may be explained by the "post-materialist" ideological profile of the voters, which is associated with an increased sense of economic security. By contrast, the severity of the economic crisis in Greece forced SYRIZA to change its focus by toning down postmaterialist issues claims as minority rights and the protection of the environment, which were central in its pre-2009 discourse to shift to traditional left issues, the most prominent of which being opposition against austerity and a radical income redistribution. This in turn helped SYRIZA to expand its audience to those who lost the most during the economic crisis. This difference between SEL and SYRIZA is highlighted by the fact 
that, all else equal, attitudes toward economic redistribution are a much better predictor of the propensity to vote for the Greek far left compared to attitudes toward immigration, while in Italy the pattern is reversed.

In the case of the far-right, the Northern League in the recent years has primarily positioned itself as an anti-immigrant, anti-European party rather than aiming at appealing to the losers of the economic crisis in Italy. On the contrary, even though the Golden Dawn started rising as a single-issue extreme party that focused almost exclusively on the issue of immigration (Dinas et al., 20I4), gradually it started promoting a scapegoating rhetoric, placing emphasis on the supposed negative role of immigration on Greece's economic woes. Consequently the party managed to attract votes from those who lost the most during the Greek economic crisis and voters who blamed immigrants for increased unemployment.

At a broader level our results point to the conclusion that economic voting extends beyond the typical and widely confirmed reward punishment hypothesis. In the case of Greece, the crisis caused a landslide for both mainstream parties, PASOK and New Democracy and brought to the fore parties from both ends of the political spectrum. As our results suggest, this trend was significantly influenced by economic hardship. It appears that in a context of severe economic shock and extreme austerity, voters are more prone to voting for radical parties. A possible explanation behind these findings is that as the crisis deepens and the space for political maneuvers is limited due to the EU imposed austerity policies, voters seek for alternatives outside of the political mainstream. In the case of Italy, economic hardship has been less severe compared to Greece, and the far-left and far-right parties did not benefit as much as their Greek counterparts from electoral shifts coming from voters struck by the crisis. Neither SEL nor the Northern League did alter fundamentally their ideological profile in order to attract the "losers" of the crisis, contrary to new alternatives such as the $\mathrm{M}_{5} \mathrm{~S}$. The main governing party has proved more resilient than expected, thanks to a recent change of leadership. Moreover, Italy did not participate in a bail-out program, which in the case of Greece required the written promises by both mainstream parties that they will keep imple- 
menting austerity policies. Overall while it is hard to make predictions over the future of the withering away of mainstream parties in crisis hit Europe, we anticipate that as the crisis deepens far left and right populist parties will increase their vote share to the expense of moderate mainstream parties.

\section{BIBLIOGRAPHY}

ANDERSON Christopher J., 2000, "Economic Voting and Political Context: A Comparative Perspective", Electoral Studies, 19-2, p.151-170.

BARTKOWSKA Monika and TIEMANN Guido, 20I4, "The Impact of Economic Perceptions on Voting Behaviour in European Parliamentary Elections", JCMS: Journal of Common Market Studies, online: <doi: I0.1 II I/jcms. 12158>.

BORDANDINI Paola, 20I3, La spada di Vendola: una risorsa o un problema per il centrosinistra?, Roma, Donzelli Editore.

BORDIGNON Fabio and CECCARINI Luigi, 2013, "Five Stars and a Cricket. Beppe Grillo Shakes Italian Politics", South European Society and Politics, 18-4, p.427-449: <doi:10.1080/13608746.2013.775720>.

BOWYER Benjamin T. and VAIL Mark I., 20II, "Economic Insecurity, the Social Market Economy, and Support for the German Left", West European Politics, 34-4, p.683-705: <doi:10.1080/01402382.2011.572387>.

CITRIN Jack, GREEN Donald P., MUSTE Christopher and WONG Cara, 1997, "Public Opinion Toward Immigration Reform: The Role of Economic Motivations", The Journal of Politics, 59-3, p.858-88I: <doi:10.2307/2998640>.

D'ALIMONTE Roberto, 2014, "High Fidelity and New Votes for Renzi" in De Sio, Emanuele and Maggini (2014), p.99-202.

DANCYGIER Rafaela and DONNELLY Michael, 20I4, "Attitudes Toward Immigration in Good Times and Bad", in Mass Politics in Tough Times, Larry Bartels and Nancy Bermeo (eds), Oxford, Oxford University Press p. 148-184: <http://www.oxfordscholarship.com/view/l0.1093/acprof: oso/9780199357505.001.0001/acprof-9780199357505-chapter-6>. 
DE SIO Lorenzo, EMANUELE Vincenzo and MAGGINI Nicola (eds), 20I4, The European Parliament Elections of 2014, Rome, CISE.

DOLEZAL Martin, 2010, "Exploring the Stabilization of a Political Force:

The Social and Attitudinal Basis of Green Parties in the Age of Globalization", West European Politics, 33-3, p.534-552: <doi:10.1080/01402381003654569>.

DUCH Raymond M. and STEVENSON Randolph T., 2008, The Economic Vote: How Political and Economic Institutions Condition Election Results, Cambridge, Cambridge University Press.

FRAILE Marta and LEWIS-BECK Michael S., 2010, "Economic Voting in Spain:

A 2000 Panel Test", Electoral Studies, 29-2, p.210-220: <doi:10.1016/j. electstud.2010.01.003>.

-, 2012, "Economic and Elections in Spain (1982-2008): Cross-Measures, Cross-

Time", Electoral Studies, Special Symposium: Economic Crisis and Elections: The European Periphery, 31-3, p.485-490: <doi:10.1016/j.electstud.2012.02.012>.

HIX Simon and MARSH Michael, 2007, "Punishment or Protest? Understanding European Parliament Elections", The Journal of Politics, 69-2, p.495-510: <doi:10. | | | //j.|468-2508.2007.00546.x>.

KNUTSEN Oddbjørn, 2004, Social Structure and Party Choice in Western Europe: A Comparative Longitudinal Study, New York, Palgrave Macmillan.

KRIESI Hanspeter, 2012, "The Political Consequences of the Financial and Economic Crisis in Europe: Electoral Punishment and Popular Protest", Swiss Political Science Review, 18-4, p.518-522: <doi:10.11 II/spsr.12006>.

-, 2014, "The Political Consequences of the Economic Crisis in Europe. Electoral Punishment and Popular Protest" in Mass Politics in Tough Times: Opinions, Votes and Protest in the Great Recession, Larry Bartels and Nancy Bermeo (eds), Oxford, Oxford University Press, p.297-333.

LEWIS-BECK Michael S. and NADEAU Richard, 2012, "PIGS or Not? Economic Voting in Southern Europe", Electoral Studies, Special Symposium: Economic Crisis and Elections: The European Periphery, 31-3, p.472-477. < doi:10.1016/j. electstud.2012.02.008>. 
LEWIS-BECK Michael S. and STEGMAIER Mary, 2000, "Economic Determinants of Electoral Outcomes", Annual Review of Political Science, 3-I, p. I83-219. $<$ doi:10.1146/annurev.polisci.3.I.183>.

-, 2007, "Economic Models of Voting", in The Oxford Handbook of Political Behaviour, R.J. Dalton and H.-D. Klingemann (eds), Oxford, Oxford University Press, p.5I8-537.

LOBO Marina Costa and LEWIS-BECK Michael S., 20I2, "The Integration Hypothesis: How the European Union Shapes Economic Voting", Electoral Studies, Special Symposium: Economic Crisis and Elections: The European Periphery, 31-3, p.522-528: <doi:10.1016/j.electstud.2012.02.004>.

NEZI Roula, 2012, "Economic Voting under the Economic Crisis: Evidence from Greece", Electoral Studies, Special Symposium: Economic Crisis and Elections: The European Periphery, 31-3, p.498-505: <doi:10.1016/j.electstud.2012.02.007>. PASSARELLI Gianluca, 2013, "Extreme Right Parties in Western Europe: The Case of the Italian Northern League", Journal of Modern Italian Studies, I8-I, p.53-7I: <doi:10.1080/135457|X.2013.730273>.

REIF Karlheinz and SCHMITT Hermann, 1980, "Nine Second-Order National Elections: A Conceptual Framework for the Analysis of European Elections Results", European Journal of Political Research, 8, p.3-44.

SAUGER Nicolas, DEHOUSSE Renaud, GOUGOU Florent, 2015, "Comparative Electoral Dynamics in the European Union in 2014 (CED-EUI4): A Data User's Guide", Les Cahiers européens de Sciences Po, n²2.

VAN DER EIJK Cees and FRANKLIN Mark N.. 1996, Choosing Europe?

The European Electorate and National Politics in the Face of Union, Ann Arbor, University of Michigan Press.

VAN DER EIJK Cees, VAN DER BRUG Wouter, KROH Martin and FRANKLIN Mark, 2006, "Rethinking the dependent variable in voting behavior: On the measurement and analysis of electoral utilities", Electoral Studies, 25-3, p.424-447.

VASILOPOULOS Pavlos, BEAUDONNET Laurie and CAUTRES Bruno, 2014, "A Red Letter Day: Investigating the Renaissance of the French Far Left in the 2012 Presidential Election", Paper presented at the 2014 MPSA conference. 